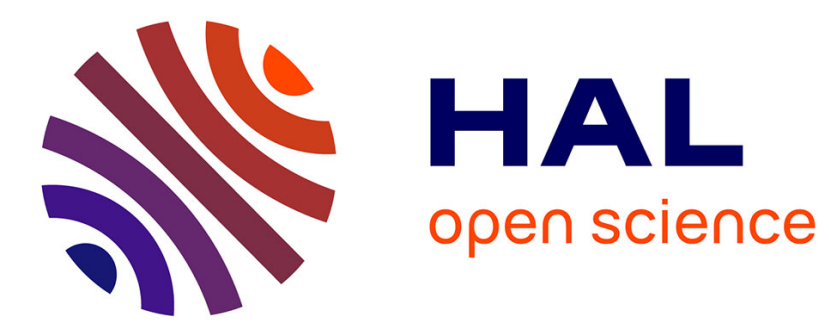

\title{
Challenging the promotion of antidepressants for nonsevere depression
}

\author{
A Braillon, J Lexchin, J H Noble, D Menkes, L M'Sahli, K Fierlbeck, A \\ Blumsohn, Florian Naudet
}

\section{- To cite this version:}

A Braillon, J Lexchin, J H Noble, D Menkes, L M'Sahli, et al.. Challenging the promotion of antidepressants for nonsevere depression. Acta Psychiatrica Scandinavica, 2019, 139 (3), pp.294-295. 10.1111/acps.13010 . hal-02049821

\section{HAL Id: hal-02049821}

\section{https://hal-univ-rennes1.archives-ouvertes.fr/hal-02049821}

Submitted on 13 Mar 2019

HAL is a multi-disciplinary open access archive for the deposit and dissemination of scientific research documents, whether they are published or not. The documents may come from teaching and research institutions in France or abroad, or from public or private research centers.
L'archive ouverte pluridisciplinaire HAL, est destinée au dépôt et à la diffusion de documents scientifiques de niveau recherche, publiés ou non, émanant des établissements d'enseignement et de recherche français ou étrangers, des laboratoires publics ou privés. 


\section{Letter to the editor}

\section{Challenging the promotion of antidepressants for nonsevere depression}

The editorial by Eriksson and Hieronymus promoting antidepressants in nonsevere depression is seriously biased and misleading (1).

Firstly, the authors merely adapted, without critical review, Furukawa et al.'s (2) study of placebo-controlled, doubleblind randomized trials of new generation antidepressants in Japan. Although Furukawa et al. initially identified 11 trials for inclusion, sponsoring companies only agreed to provide access to patient-level data for six. Two of these could not be included in the primary analysis because the data were only available through a remote portal. Further, the trials lasted for only 6-8 weeks and the authors did not report on adverse effects. Furukawa et al. found that the efficacy of antidepressants was below the level of clinical relevance (1.62 points [95\% Confidence interval, 0.81-2.43] on the Hamilton Depression Rating Scale (HDRS) at 8 weeks). Eriksson and Hieronymus conclude that the impact of baseline severity on antidepressant response is a myth, while the more important conclusion is that the only available evidence is from shortterm trials, based on surrogate measures, ignores adverse effects, and indicates only minimal efficacy of antidepressants.

Secondly, Eriksson and Hieronymus fail to acknowledge the general limitations of trials such as those included in the Furukawa et al. analysis. Crucially, these trials measure antidepressant effectiveness using depression scales that are frankly inadequate to assess well-being and functional outcomes. Indeed, only 1 item out of 17 in the HDRS and no items in the Montgomery-Åsberg Depression Rating Scale measure well-being. Moreover, sexual function, frequently impaired by antidepressants, is ignored. The trials included in Furukawa et al. thus provide essentially no information about quality of life or recovery of function. Cipriani et al. (3), in a recent meta-analysis of 522 antidepressant trials $(n=116477)$, highlighted that no data were available to quantify global functioning, acknowledged to be a highly relevant clinical outcome.

Thirdly, antidepressants as a class deserve high degree of scrutiny. Recent critical evaluations have exposed how pharmaceutical industry-sponsored studies have overestimated benefits and underestimated harms (4-7). This is especially true considering the potential for serious harms from antidepressants compared to psychotherapy. Serious adverse effects of antidepressants, including suicide, cannot be overlooked. In 2004, the Food and Drug Administration issued a black-box warning for all antidepressants indicating an association with increased suicidality $(8,9)$. Other serious adverse effects also exist. There is no evidence that escitalopram or citalopram is superior in terms of efficacy compared to other antidepressants but robust documentation has existed since 2001 linking them to serious cardiovascular adverse effects (QT prolongation and deadly torsade de pointes) (10, 11). Similarly, duloxetine has no efficacy advantage versus other antidepressants, but has the potential for life-threatening liver injury and severe skin reactions, including Stevens-Johnson syndrome (12, 13). Escitalopram and duloxetine, included in the Furukawa et al. study, feature in the yearly list of 'drugs to avoid' published by the independent drug bulletin Prescrire International, having been assessed to be more dangerous than beneficial (14). In addition, another selective serotonin reuptake inhibitor included in the Furukawa study, paroxetine, increases the risk of cardiac anomalies (15), a major concern as there are more prescriptions for paroxetine than for any other antidepressant among women of child bearing age (16) and many pregnancies are unplanned $(45 \%$ in the United States in 2011) (17).

Finally, there is justifiable concern about the overdiagnosis of depression in people's lived experience, where mood perturbations commonly reflect real life more than medical illness. Indeed, they are often understandable and temporary reactions to loss, bereavement, or other stressors. Many depressive presentations respond to judicious 'watchful waiting' (18) and support. Most episodes of depression that persist are often successfully treated with specific psychosocial interventions, notably cognitive behavioral therapy (CBT), interpersonal psychotherapy, or behavioral activation. These treatments, robustly evidence-based in the real-life setting and over the long term $(19,20)$, are often preferred by patients(21) and known to improve self-esteem, agency, and social functioning (22). Unfortunately, antidepressant treatment is far more likely to be reimbursed by healthcare systems than are psychosocial interventions. Given the lack of evidence for the superiority of antidepressants over the long term, and in light of the harms they can cause, (23-25) psychosocial interventions remain the preferred first option for most patients with nonsevere depression. This is the recommendation of many national guidelines such as the one from the Canadian Network for Mood and Anxiety Treatments (26).

In conclusion, available evidence shows only very limited effectiveness of antidepressants for nonsevere depression. In light of this, and their potential harms, their routine use for this indication cannot be justified; the editorial by Eriksson and Hieronymus thus seriously misrepresents the utility of antidepressant medication for nonsevere depression.

\section{Acknowledgements}

We thank Leemon McHenry for discussions.

\section{Declaration of interests}

$\mathrm{JL}$ received payment for being on a panel that discussed a pharmacare plan for Canada (Canadian Institute, a for-profit organization). He is member of the Foundation Board of Health Action International and the Board of Canadian Doctors for Medicare. JL and KF are members of 'The Jean Monnet Network in Health Law and Policy' funded by the 
European Union (http://jmhealthnet.org/). DM is an associate member of the International Society of Drug Bulletins (http:// www.isdbweb.org/). Others have nothing to declare.

A. Braillon ${ }^{1}$ D , J. Lexchin ${ }^{2}, J$. H. Noble ${ }^{3}$, D. Menkes ${ }^{4}$,
L. M'sahli ${ }^{5}$, K. Fierlbeck ${ }^{6}$, A. Blumsohn ${ }^{7, *}, F$. Naudet
8
${ }^{1}$ University Hospital, Amiens, France, ${ }^{2}$ School of Health Policy
and Management, York University, Toronto, ON, Canada,
${ }^{3}$ State University of New York at Buffalo, Georgetown, TX,
USA, ${ }^{4}$ Waikato Clinical Campus, University of Auckland,
Auckland, New Zealand, ${ }^{5}$ Council of the National Anti-
Corruption Authority (INLUCC), Tunis, Tunisia, ${ }^{6}$ Department
of Political Science, Dalhousie University, Halifax, NS,
Canada, ${ }^{7}$ University of Sheffield, Sheffield, UK and ${ }^{8}$ INSERM
CIC-P 1414 and University Hospital, Rennes, France
E-mail: braillon.alain@gmail.com
*Previously Senior Lecturer in Medicine.

\section{References}

1. Eriksson E, Hieronymus F. The alleged lack of efficacy of antidepressants in non-severe depression: a myth debunked. Acta Psychiatr Scand 2018;137:447-449.

2. Furukawa TA, Maruo K, Noma $\mathrm{H}$ et al. Initial severity of major depression and efficacy of new generation antidepressants: individual participant data meta-analysis. Acta Psychiatr Scand 2018;137:450-458.

3. Cipriani A, Furukawa TA, Salanti $G$ et al. Comparative efficacy and acceptability of 21 antidepressant drugs for the acute treatment of adults with major depressive disorder: a systematic review and network meta-analysis. Lancet 2018;7:1357-1366.

4. Jureidini JN, Amsterdam JD, McHenry LB. The citalopram CIT-MD-18 pediatric depression trial: deconstruction of medical ghostwriting, data mischaracterisation and academic malfeasance. Int J Risk Saf Med 2016;28:33-43.

5. Turner EH, Matthews AM, Linardatos E, Tell RA, RosenтнаL R. Selective publication of antidepressant trials and its influence on apparent efficacy. $\mathrm{N}$ Engl J Med 2008;358:252-260.

6. Moncrieff J, Kirsch I. Empirically derived criteria cast doubt on the clinical significance of antidepressant-placebo differences. Contemp Clin Trials 2015;43:60-62.

7. Ebrahim S, Bance S, Athale A, Malachowski C, Ioannidis JP. Meta-analyses with industry involvement are massively published and report no caveats for antidepressants. J Clin Epidemiol 2016;70:155-163.

8. FRIEDMAN RA. Antidepressants' black-box warning10 years later. N Engl J Med 2014;371:1666-1668.

9. Healy D, Whitaker C. Antidepressants and suicide: risk-benefit conundrums. J Psychiatry Neurosci 2003;28: 331-337.

10. Catalano G, Catalano MC, Epstein Ma, Tsambiras Pe. QTc interval prolongation associated with citalopram overdose: a case report and literature review. Clin Neuropharmacol 2001;24:158-162.

11. Ojero-Senard A, Benevent J, Bondon-Guitton E et al. A comparative study of QT prolongation with serotonin reuptake inhibitors. Psychopharmacology 2017;234:3075-3081.
12. Wernicke J, Pangallo B, Wang $F$ et al. Hepatic effects of duloxetine-I: non-clinical and clinical trial data [published erratum in Curr Drug Saf 2009; 4:94]. Curr Drug Saf 2008:3:132-142.

13. US Food and Drug Administration. Cymbalta (duloxetine hydrochloride). Silver Spring (MD): US Food and Drug Administration; 2011. Available: www.fda.gov/Safety/ MedWatch/SafetyInformation/ucm255064.htm

14. Prescrire. Towards better patient care: drugs to avoid in 2018. Prescrire Int 2018;27:107-111.

15. Malm H, Artama M, Gissler M, Ritvanen A. Selective serotonin reuptake inhibitors and risk for major congenital anomalies. Obstet Gynecol 2011;118:111-120.

16. Ekhart C, van Hunsel F, Scholl J, de Vries S, van PuijenBROEK E. Sex differences in reported adverse drug reactions of Selective Serotonin Reuptake Inhibitors. Drug Saf 2018;41:677-683.

17. Finer LB, Zolna MR. Declines in unintended pregnancy in the United States, 2008-2011. N Engl J Med 2016;374: 843-852.

18. Iglesias-González M, Aznar-Lou I, Gil-Girbau M et al. Comparing watchful waiting with antidepressants for the management of subclinical depression symptoms to mildmoderate depression in primary care: a systematic review. Fam Pract 2017;34:639-648.

19. Wiles NJ, Thomas L, Turner $\mathrm{N}$ et al. Long-term effectiveness and cost-effectiveness of cognitive behavioural therapy as an adjunct to pharmacotherapy for treatmentresistant depression in primary care: follow-up of the CoBalT randomised controlled trial. Lancet Psychiatry 2016:3:137-144

20. Richards DA, Ekers D, McMillan D et al. Cost and Outcome of Behavioural Activation versus Cognitive Behavioural Therapy for Depression (COBRA): a randomised, controlled, non-inferiority trial. Lancet 2016;388:871-880.

21. McHugh RK, Whitton SW, Peckham AD, Welge JA, Otto MW. Patient preference for psychological vs pharmacologic treatment of psychiatric disorders: a meta-analytic review. J Clin Psychiatry 2013;7:595-602.

22. Kolovos S, Kleiboer A, Cuispers P. Effect of psychotherapy for depression on quality of life: meta-analysis. Br J Psychiatry 2016;209:460-468.

23. Cox GR, Callahan P, Churchill R et al. Psychological therapies versus antidepressant medication, alone and in combination for depression in children and adolescents. Cochrane Database Syst Rev 2014;(11):CD008324.

24. Amick HR, Gartlehner G, Gaynes BN et al. Comparative benefits and harms of second generation antidepressants and cognitive behavioral therapies in initial treatment of major depressive disorder: systematic review and metaanalysis. BMJ 2015;351:h6019.

25. Thase ME, Friedman ES, Biggs MM et al. Cognitive therapy versus medication in augmentation and switch strategies as second-step treatments: a STAR*D report. Am J Psychiatry 2007;164:739-752.

26. Parikh SV, Quilty LC, Ravitz $P$ et al. Canadian Network for Mood and Anxiety Treatments (CANMAT) 2016 clinical guidelines for the management of adults with major depressive disorder: section 2. Psychological treatments. Can J Psychiatry 2016;61:524-539. 